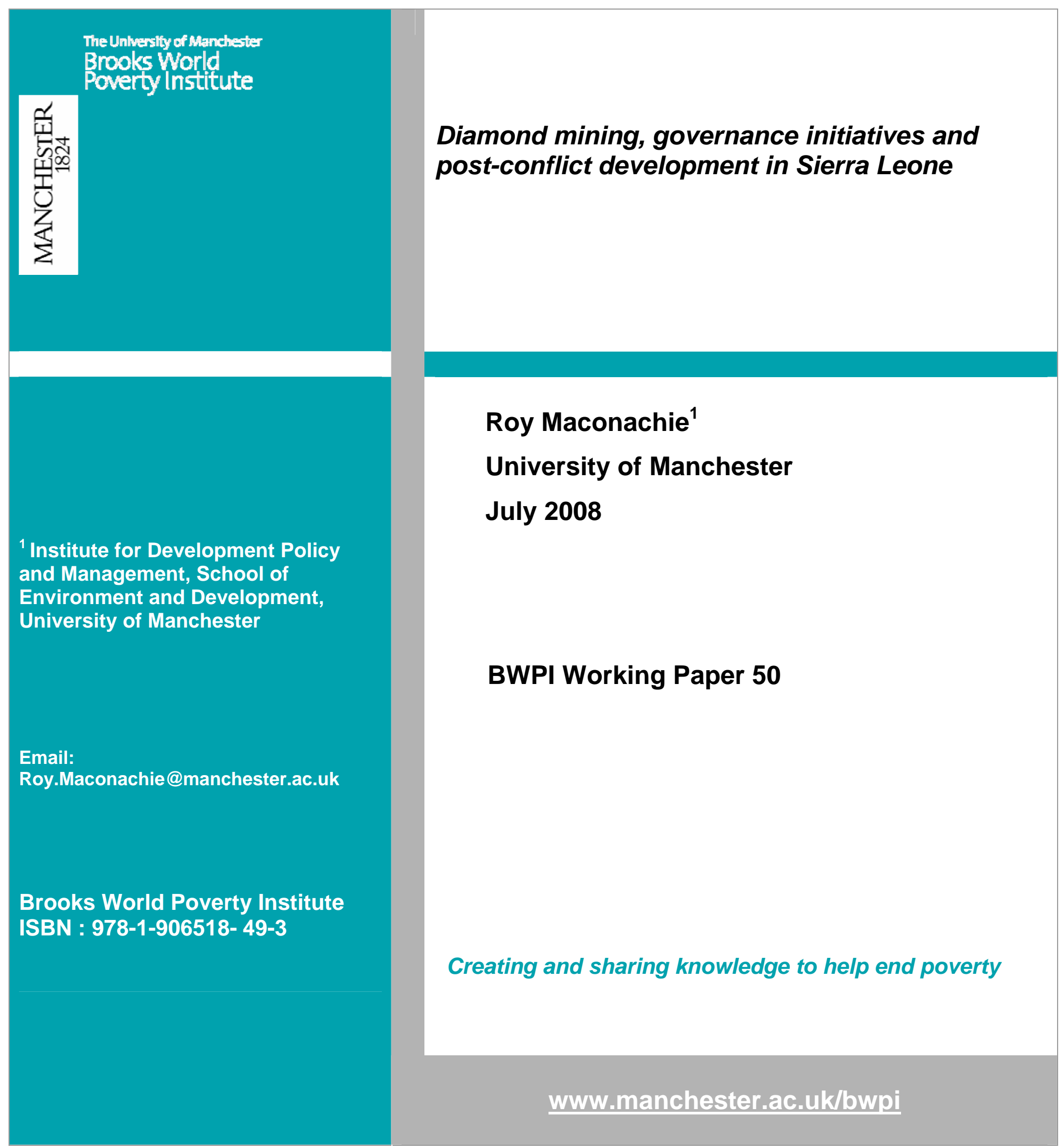




\title{
Diamond mining, governance initiatives and post-conflict development in Sierra Leone
}

\begin{abstract}
This paper critically examines some of the main challenges associated with facilitating 'good governance' in small-scale diamond mining communities, focusing on the experience of Sierra Leone. Two recent governance initiatives in the country's diamond sector are reviewed: the Kimberley Process Certification Scheme (KPCS) for rough diamonds and the Diamond Area Community Development Fund (DACDF). The analysis considers some of the broader lessons which have emerged, as Sierra Leone currently attempts to launch a third governance initiative: the Extractive Industries Transparency Initiative (EITI). It is argued that the introduction of complex monitoring processes represents significant challenges for a country which is emerging from a long period of conflict and isolation, is suffering from serious shortages in human capacity, and where good governance, accountability and transparency will undoubtedly take considerable time to develop.
\end{abstract}

Keywords: diamond mining, Sierra Leone, governance, conflict, transparency, accountability, minerals.

\section{Acknowledgements}

The research on which this paper is based was funded by a grant from the Nuffield Foundation. The author would like to thank Gavin Hilson and lan Smillie for their useful comments on an earlier draft of the paper. 


\section{Introduction}

In recent years, a burgeoning body of research has examined the links between 'lootable' resources, poor governance and underdevelopment in sub-Saharan Africa (Collier and Hoeffler, 2005; Campbell, 2003; Mbabazi et al., 2002). Proponents of the 'resource curse' hypothesis argue that African countries with significant natural wealth reap limited rewards and have experienced underdevelopment, corruption, political instability, and in some cases, violent conflict (Elbadawi and Sambanis, 2002; Collier and Hoeffler, 2001). A number of scholars (e.g. Ross, 2003; Fearon, 2004) have observed a strong correlation between lootable resources - those which have high value-to-weight ratios, and can be easily appropriated and transported by unskilled workers - and political disorder; and, by extension have argued that lootable wealth has the propensity to fuel 'greed-based' insurgency in collapsed states. The nexus between lootable resource wealth, poor governance, underdevelopment and conflict, it is argued, may be particularly prominent in failing states where there are large deposits of alluvial minerals that are mined 'artisanally', and it remains virtually impossible to monitor or regulate their extraction.

A number of commentators have argued that the panacea for the resource curse is better governance: both governments and extractive industry companies operating in developing countries must commit to higher standards of transparency and accountability (Ocheje, 2006; Labonne, 1999). In the last decade in particular, the relationship between 'good governance', natural resource management and positive development outcomes has returned to centre stage on international policy agendas. Specifically, there has been growing awareness that in managing natural resources and their revenues, better attention to governance can reduce poverty, facilitate economic growth and promote more meaningful development (ODI, 2006).

However, despite the fanfare accompanying overwhelming support for prescriptions of 'good governance' in the developing world, there has been comparatively little academic research concerned with identifying ways to improve governance and transparency in lootable economies. In the context of Sierra Leone - the focus of this paper - the most recent UNDP Human Development Report suggests that the key emerging post-conflict challenges to be pursued by both government and citizens relate to governance, including accountability, transparency and corruption (UNDP, 2007a: 28). Although there is an evolving agenda for greater corporate and governmental accountability in issues that concern development and human rights in the extractive industries in Sierra Leone, the rich diversity of regulatory codes of 'best practice' are not legally binding. These codes are essentially voluntary, yet the impetus behind their implementation is to facilitate improved governance, transparency and community development: keys to moving Sierra Leone's diamond mining industry forward.

Moving beyond debates on the 'resource curse' hypothesis and 'greed vs. grievance' thesis, this paper critically examines some of the main challenges with promoting 'good governance' in artisanal and small-scale mining communities in sub-Saharan Africa, focusing on the case of Sierra Leone's post-conflict diamond economy. The analysis draws upon recent field-based research undertaken in two diamondiferous communities in the Eastern Province: Kayima in Kono District and Panguma in Lower Bambara District (see Figure 1). Following a brief review of the role that diamonds have assumed in Sierra Leone's development trajectory to date, and how this ties into larger debates that may concern the resource curse, two important governance initiatives in the 
country's diamond economy are considered: the Kimberley Process Certification Scheme (KPCS) for rough diamonds and the Diamond Area Community Development Fund (DACDF). The paper concludes by considering the broader lessons which have emerged from these two initiatives, by briefly exploring their implications for the effective implementation of the Extractive Industries Transparency Initiative (EITI) - a policy mechanism recently adopted in Sierra Leone that Western donors and governments believe to be a key to facilitating economic improvement in resource-rich developing countries.

Figure 1: Sierra Leone: Location of Kayima and Panguma

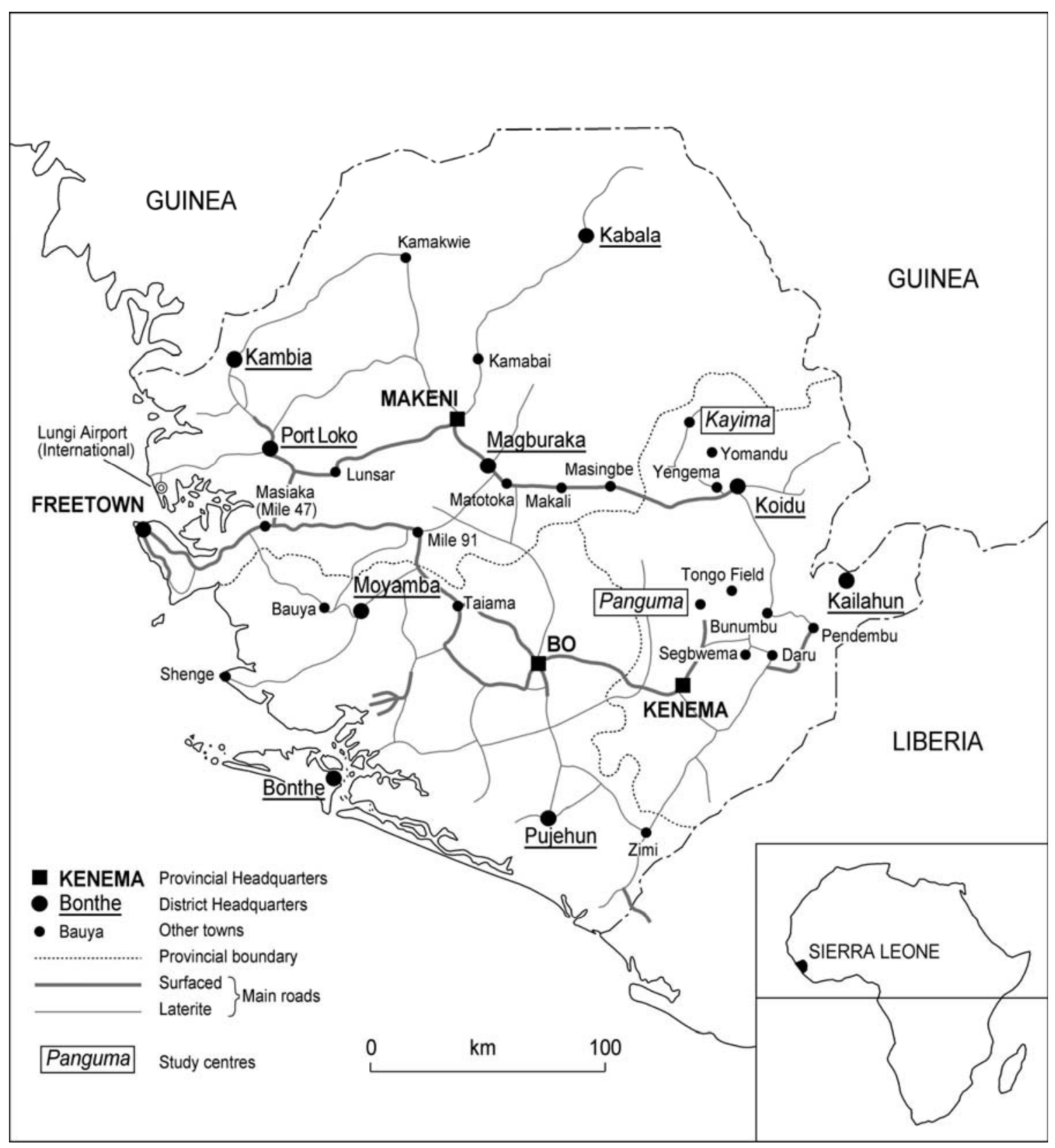


Sierra Leone has recently emerged from a long period of political instability and civil war. The most recent UNDP economic and social development indicators suggest that it is once again the poorest country in the world (UNDP 2007b). The country's economy was already nearing a state of collapse at the end of the 1980s, following years of poor governance and economic mismanagement under Siaka Stevens' APC government, but the protracted conflict of the 1990s destroyed most of the country's basic social and economic infrastructure, and extreme poverty became widespread and deeply entrenched. While significant academic attention has focused on the political economy of the war and the ensuing debate over whether or not diamonds were responsible for fuelling 'greed-based' insurgency (e.g. see Keen, 2005; Richards, 2003; Smillie et al. 2000), the 'Conflict Diamond' campaign of the 1990s launched by a coalition of well-known NGOs and civil society groups has been instrumental in drawing wider public attention to the link between diamonds and war (Hilson, 2008). The recent release of a major Hollywood film has further galvanized public concern for 'blood diamonds', which, it has been suggested, played a key role in prolonging Sierra Leone's debilitating conflict.

The causes of Sierra Leone's decade-long civil war were complex, and an extended discussion of the events leading up to the conflict is beyond the scope of this paper. ${ }^{1}$ There does, however, appear to be some consensus amongst commentators that poor governance and the creation of a socially-excluded underclass were responsible for fomenting the pre-conditions for war. Diamonds, it is argued, played a central role in fuelling the conflict as various parties funded their war efforts through mining activities. While it is undoubtedly the case that decades of diamond smuggling in Sierra Leone have contributed to the corruption of the government, deprived the country of millions of dollars in development revenue and fostered political instability more broadly within the West African sub-region (Gberie, 2002), there continues to be much debate as to the role that diamonds might assume in the country's future development path.

On the one hand, a number of observers have cautioned that diamonds still present a significant security threat in the post-conflict period: as large numbers of former combatants continue to return to diamond mining areas in the Eastern Province, concerns about the socioeconomic consequences of mining remain widespread. A number of commentators have warned that without significant efforts to provide better socioeconomic opportunities for sociallyexcluded rural youth, there is a considerable risk that violence could resume once again. A recent report by the Washington D.C.-based development consultancy firm, Management Systems International (MSI), provides further cause for alarm, noting that a large percentage of Sierra Leone's diamonds continue to be mined and exported illegally. Consequently, only a tiny proportion of the value on the European market value of the exports (approximately 10-15\%) remains to be split among some 200,000 to 400,000 miners and diggers. These $15-30$ year-old males, the report notes, are the very demographic group that is most likely to resume warfare if left unattended (MSI, 2004: 7).

On the other hand, despite extreme levels of poverty in present-day Sierra Leone, particularly in the diamondiferous regions themselves, there was, in fact, a time when diamonds played an important role in the country's national development agenda and were a significant feature of the local economies and societies where they were mined. Prior to the onset of war in 1991, mining was by far the most important foreign exchange earner for the country, accounting for some 80 per cent of export earnings and 20 per cent of GDP (NMJD, 2007). Diamonds were

\footnotetext{
${ }^{1}$ While an understanding of the factors leading up to the war remains important, much has been written on this elsewhere. See, for example, Noyes (2003), Adebajo (2002) or Richards (1996).
} 
discovered in Kono District in the Eastern Province in 1930, and early reports suggest that in 1934, when the main mining company - Sierra Leone Selection Trust (SLST) - was established, there was a considerable amount of revenue being reinvested in 'local' development. Employees of the SLST were not only provided with relatively well-paid jobs, but they also received a range of associated benefits, including schooling for their children, university scholarships, housing and medical care. In 1970, the Sierra Leone Government acquired a 51 per cent share in SLST, and the National Diamond Mining Company (NDMC) was formed. It used highly mechanised methods, involving draglines, earth-moving equipment and sophisticated treatment plants to extract diamonds from the gravels. The establishment of the Alluvial Diamond Mining Scheme (ADMS) in 1955 meant that indigenous Sierra Leoneans could also apply for mining licences to extract diamonds in designated areas outside the two mining company leases in Yengema (Kono District) and Tongo Field (Kenema District). During these early days, diamond revenues were used to finance infrastructure development, including road construction, and the provision of clean drinking water and electricity. As a result, the diamondiferous areas - most notably in Kono and Kenema Districts - prospered and were important drivers of economic growth.

Today, the sustainable development of the country's valuable mineral resources - which includes not only diamonds but also gold, rutile, bauxite and iron ore - is a government priority and has been a central tenet of the National Recovery Strategy (NRS) launched in October 2002, and the Poverty Reduction Strategy Paper (PRSP) of March 2005. Whilst industry critics note that the ADMS licensing scheme introduced by the government in the 1950s was not without its problems, it has been suggested that more attention must be given to the governance of diamonds: controlling their buying, trading and smuggling, and ensuring that the appropriate financial awards are returned to diamondiferous communities. Not only does the government regard the revival of the mining sector as one of the main sources of economic growth and poverty reduction (NRS, 2002), but as Maconachie and Binns (2007) maintain, if diamond capital was reinvested into the local economy, it could also provide an impetus for post-conflict development and the restoration of rural livelihoods. The authors note that the 'dovetailing' of artisanal diamond mining activities with the local farming economy is vital to rural livelihood portfolios, especially in light of changing patterns of livelihoods diversification and the rise of non-farm work that is occurring more widely across sub-Saharan Africa (e.g. see Bryceson and Jamal, 1997; Ellis, 1998).

With escalating energy and raw material demands from the so-called BRIC countries (Brazil, Russia, India and China) and increasing commodity prices on the world market, there is now renewed global interest in minerals and natural resources throughout Africa. Moreover, in a post 9-11 world, the continuing U.S. quest for non-Islamic oil and strategic minerals (i.e. those that are militarily, politically or economically essential), has, in many respects, led to a 'second scramble for Africa' amongst powerful transnational corporations. In this context, Sierra Leone is currently witnessing a resurgence of activities in the mining sector. Information obtained from the Ministry of Mineral Resources in February 2008 indicates that there are presently over 50 non-artisanal mining companies officially registered in the country.

In short, more than ever before, there is now a pressing need to critically re-examine how national resource management policies become contextualised within international strategies that are driven by the way the global political economy currently shapes both resource use and its governance. Perhaps more importantly, how is this reflected at the local level? Within Sierra Leone's artisanal and small-scale diamond mining sector, the question of how the governance of 
diamonds and trade could be better harnessed for poverty reduction, economic growth and social development needs to be explored in further detail. In this vein, in the next two sections of the paper, the analysis turns to two well known diamond governance initiatives that (in theory) aim to play an important role in the country's post-conflict development trajectory: the Kimberley Process Certification Scheme (KPCS) for rough diamonds and the Diamond Area Community Development Fund (DACDF).

\section{The Kimberley Process Certification Scheme (KPCS)}

The most well known and internationally acclaimed governance initiative in Sierra Leone's diamond industry, the KPCS, has been widely heralded as a possible way forward in breaking the link between the legitimate trade in diamonds and uncontrolled 'conflict' diamonds. Since the end of the country's diamond-fuelled civil war in 2002, the issue of conflict diamonds has captivated the attention of researchers, policy makers and the media, both within Sierra Leone and internationally. Indeed, even before the official launch of the KPCS in 2003, a UN diamond certificate scheme had been introduced in Sierra Leone in October 2000, to ensure that diamonds for export were not being derived from rebel-held areas. This earlier scheme conforms with the KPCS and continues to be used in Sierra Leone to this day.

The origins of the KPCS itself can be traced to a series of meetings held in Kimberley, South Africa, beginning in May 2000, where governments, NGOs and the private sector initially met to address the problem of conflict diamonds. Following intense negotiations involving 35 countries, by December of that same year, the UN General Assembly had adopted a resolution supporting the creation of an international certification scheme for rough diamonds. However, it was not until almost two years later in November 2002, that the scheme was finally adopted at a ministerial meeting in Interlaken, Switzerland ${ }^{2}$. On January 1, 2003, the scheme officially took effect, with over 45 signatory countries, including Sierra Leone. Today, the KPCS is held up by many industry observers to be the 'gold standard' of voluntary corporate social responsibility mechanisms and it is now backed by national legislation in more than 70 countries $^{3}$.

On a positive note, the KPCS has indeed been a success story in Sierra Leone in that it has forced a large volume of illicit diamonds out of underground networks and into official channels. Referring to Table 1, for example, it apparent that since the introduction of the KPCS in Sierra Leone, diamond exports through the Government Gold and Diamond Office (GGDO) have increased significantly. In particular, when diamond export figures from 1999 (prior to the launch of the first UN certificate scheme) are compared with those from 2000 (after the first year of the scheme), a significant increase can be detected. Moreover, a further sharp rise in export earnings can also be seen in 2003 when kimberlite production was first initiated. Needless to say, this increased revenue generation has been vital for the reconstruction of community structures and

\footnotetext{
2 Reports suggest that although negotiations were slowed down by the commercial interests of the governments of several countries, including Russia, China and the US, the overall negotiation period for the KPCS took place in record time for an international agreement.

${ }^{3}$ According to the terms of the KPCS, each participating government must issue a certificate to accompany all rough diamonds being exported from within its borders, to ensure that they are 'conflict free'. Each country must therefore be able to track the diamonds being exported to their place of origin, or to the point of import, and it must meet a set of standards for these internal controls. All participating countries must also agree not to import any rough diamonds without an approved KPCS certificate.
} 
war damaged infrastructure. As Davies notes (2006: 178), 'although conceived for blood or conflict diamonds, the Kimberley Process is proving useful in Sierra Leone's post-conflict context'.

Table 1: Diamond exports from Sierra Leone: 1998-2006 (GGDO)

\begin{tabular}{|l|l|l|l|}
\hline \multicolumn{1}{|c|}{ Year } & \multicolumn{1}{|c|}{ Carats } & \multicolumn{1}{|c|}{ Value (US \$) } & \multicolumn{1}{|c|}{$\begin{array}{c}\text { Duty, 3 percent (US } \\
\text { \$) }\end{array}$} \\
\hline 1998 & $15,818.04$ & $1,780,287.41$ & $53,408.22$ \\
\hline 1999 & $9,320.32$ & $1,244,825.34$ & $37,344.76$ \\
\hline 2000 & $77,372.39$ & $10,066,920.81$ & $302,007.62$ \\
\hline 2001 & $222,519.83$ & $26,022,492.27$ & $780,674.77$ \\
\hline 2002 & $341,859.23$ & $41,732,130.29$ & $1,251,964.71$ \\
\hline 2003 & $506,723.37$ & $75,969,753.32$ & $2,193,335.84$ \\
\hline $2004(+)$ & $499,242.43(\mathrm{~A})$ & $89,618,053.54$ & $2,688,541.60$ \\
\hline $2004(+)$ & $58,030.54(\mathrm{~K})$ & $11,172,434.79$ & $335,173.04$ \\
\hline 2005 & $552,044(\mathrm{~A})$ & $119,429,528$ & $3,582,885.84$ \\
\hline 2005 & $116,665(\mathrm{~K})$ & $22,510,716$ & $675,321.48$ \\
\hline $2006\left(^{*}\right)$ & $209,762(\mathrm{~A})$ & $45,535,966$ & $1,366,078.98$ \\
\hline $2006\left(^{*}\right)$ & $30,631(\mathrm{~K})$ & $6,984,425$ & $209,532.75$ \\
\hline
\end{tabular}

(+) Figures from January to September 2004

$\left(^{\star}\right)$ Figures from January to June 2006

(A) Alluvial, (K) Kimberlite

Source: Strasser-King (2004: 9) and GGDO Diamond Export Figures, 2001-2006

However, although the KPCS may be an important governance initiative for redressing the serious humanitarian and security problems associated with conflict diamonds, and despite possibly playing a role in increasing export earnings for the government, there are also a number of key problems associated with its implementation in Sierra Leone. Foremost, the geological nature of diamond deposits in Sierra Leone makes their governance and trade exceptionally challenging. Typically, diamonds come from volcanic breccias occurring as diamondiferous dykes, known commonly as 'kimberlites'. Although Sierra Leone's diamonds can be found in kimberlite pipes, as is common in South Africa or Botswana, they are more commonly dispersed in the gravels of river beds and terraces as alluvial deposits. Two river systems, the Sewa and its tributaries, flowing through Bo and Bonthe Districts, and the Moa, flowing through Kenema and Pujehun Districts, have deposited diamonds over large areas in the south and east of Sierra Leone (see Figure 1). In areal extent, the country's alluvial diamond mining fields cover almost 20,000 sq km, though the actual diamond-bearing alluvial ground is actually about $200 \mathrm{~km}^{2}$. Often, these deposits are spread across national and chiefdom boundaries.

In contrast to South Africa, where diamond mining is associated with the mechanical mining of deep reserves, in Sierra Leone it is not unheard of to find a good quality diamond on the ground surface, particularly after rain. As such, an estimated 80 percent of diamond mining in the country is carried out by 'artisanal' methods, and involves little more than digging and sifting through river- 
bank mud, sand or gravel with picks, shovels, buckets and sieves. Unlike deep-pit kimberlite mining, which can be fenced off and monitored carefully, artisanal mining remains virtually impossible to regulate or control because there are relatively few diamonds per hectare, people tend to actually live where the diamonds are located, and labour intensive mining techniques are common. Consequently, owing to the highly lootable character of Sierra Leonean diamonds and the ease at which they can be appropriated, there has been a well-established history of smuggling in the country which long predates the onset of the war ${ }^{4}$. Even though the Kimberley Process is a relatively effective international governance initiative that has drastically stemmed the flow of conflict diamonds from Africa, it is not sufficient to curb smuggling completely, given the physical nature of diamonds and the characteristics of their trade ${ }^{5}$. Some industry observers suggest that up to 50 per cent of Sierra Leone's diamonds still continue to leave the country illegally (Partnership Africa Canada and Network Movement for Justice and Development, 2006) ${ }^{6}$. Moreover, illicit diamond activities within the country have recently been implicated in regional instability in Liberia, Guinea and Cote D'lvoire, and have even been linked to international money laundering and terrorist groups (Even-Zohar, 2003; Le Billon, 2006). As was noted recently by Partnership Africa Canada (2006), perhaps the major challenge facing the Kimberley Process is to ensure that it does not become a 'paper tiger': a diamond control system which may have 'teeth' in theory, but is ineffectively implemented and enforced in practice.

While the KPCS has undoubtedly made significant inroads in addressing illicit diamond mining activities and their link to violent conflict, a number of commentators have pointed out that the initiative has done relatively little to address the poverty, inequality and desperate working conditions that small-scale miners must endure on a daily basis (Silberfein, 2004; Olsson, 2006). Indeed, the diamond diggers who work at the bottom of the supply chain must endure particularly dangerous conditions, and many live on less than a dollar a day (Global Witness/Partnership Africa Canada, 2004). It has been estimated that there may be as many as one million artisanal miners in sub-Saharan Africa who operate beyond the KPCS (DDI, 2005: 2). The Diamond Development Initiative (DDI) - founded by De Beers, Global Witness, Partnership Africa Canada, diamond sector analyst Rapaport and the World Bank - has largely grown out of the Kimberley Process, brings together governments, NGOs and the diamond industry itself, and aims to promote a more developmental focus that centres on the miners and mining communities themselves. As Smillie (2006: xii) appropriately notes, 'In the long run, better remuneration, better conditions and better alternatives are more likely to make a real difference in the artisanal mining sector than more rules,

\footnotetext{
${ }^{4}$ Early reports from the 1950s document the first instances of illegal diamond mining and smuggling in the country, and note that the SLST initially responded by increasing security measures through the deployment of armed guards and airborne patrols around mining sites (Temple, 2006). According to Van der Laan (1965), between 1952 and 1955, illegal miners were producing and smuggling diamonds valued at approximately $£ 5.4$ million each year. However, illegal mining continued to grow and became impossible to police, and by the time Siaka Stevens came to power in 1968, the diamond industry had been reduced to a parastatal that was rife with corruption and smuggling. Over the following 17 years that Stevens retained power, official diamond exports fell from 1.7 million carats in the 1960 s, to just 50,000 carats by 1985 (Temple, 2006).

${ }^{5}$ As such, some critics speak of the need for a 'Kimberley II Process', to address local issues that encourage smuggling and impede enforcement (see Strasser-King, 2004). While the USAID-funded Peace Diamond Alliance initially laid the foundations for such an initiative immediately following the war, more recently, the Diamonds for Development (DDI) initiative has continued to strive for such a process.

6 Davies (2006:178) explains that the combination of requirements to pay an exporter's licence fee of US $\$ 30,000$ per year, the export tax of 3 per cent, and the additional payments which must be made through bribes, have all contributed to discouraging legal production.
} 
more antipathy and more peacekeeping'. In this light, a number of other projects funded by major international donors - such as the now disbanded Peace Diamond Alliance (PDA) or the Integrated Diamond Management Programme (IDMP) - have attempted to address some of the shortcomings of the KPCS, and introduce innovative new models of resource governance in the diamond industry ${ }^{7}$. As such, the next section of the paper examines one such governance mechanism initiated by the Peace Diamond Alliance and the Sierra Leonean government, that is attempting to address some of these particular developmental issues.

\section{The Diamond Area Community Development Fund (DACDF)}

Over the past few decades, community-based, decentralized and participatory approaches to natural resource management have become 'standard practice' in development agendas across sub-Saharan Africa. Building on the popularity of previous community-based natural resource management (CBNRM) experiments elsewhere in Africa, the Diamond Area Community Development Fund (DACDF) was formally approved by Sierra Leone's Ministry of Mineral Resources in December 2001, as part of a broader reform programme for the diamond sector following the end of the war. Like other CBNRM initiatives elsewhere in Africa, such as CAMPFIRE in Zimbabwe or Gestion des Terroirs in Mali, the DACDF adopts participatory mechanisms which aim to allow local actors to exercise their natural resource management responsibilities and decision-making powers. In addition, the fund has been widely heralded by proponents as providing considerable incentive for both miners and diamond-rich chiefdoms to engage in legal diamond mining activities and revenue reporting, by returning a percentage of mining revenue back to the producing chiefdoms. A portion of the government's 3 percent diamond export tax (which amounts to 0.75 percent export duty) is now put into the fund for community-managed small-scale development projects in diamondiferous regions; donors have been asked to match funding to the DACDF in order to further enhance social and infrastructural development (Temple, 2005).

To date, the matching arrangement by donors remains unclear. However, it is clear that an unprecedented amount of diamond revenue has been returned to diamond-mining communities since the fund was initiated. The first tranche was made for the period of January-June 2001, and disbursements have been made every six months since then. According to a recent Global Witness/Africa Canada report (2004), in 2001, US\$195,165 was returned to diamond producing communities by the DACDF; in 2002, the fund returned US $\$ 312,988$; and in 2003, US $\$ 569,000$ was returned. By the end of 2004, 54 chiefdoms with a combined total of 2,313 licences had benefited from the fund (Partnership Africa Canada/Network Movement for Justice and Development, 2006). During 2005, over US $\$ 900,000$ was reportedly returned to diamondiferous communities (GAO, 2006). There is much evidence to suggest that the fund, which is now reported to be approaching US\$3 million, has been utilized wisely by some chiefdoms and councils for financing community infrastructure, education, health and vocational skills training centres (Temple, 2005).

Chiefdoms benefit in accordance with the number of mining licences issued and the value of diamonds recovered from their territory. Funds disbursed are earmarked for specific community development projects. Comparing the two chiefdoms where fieldwork was undertaken for this paper (Sandor and Lower Bambara), reports from the Ministry of Mineral Resources (2004) suggest that by December 2003, Sandor Chiefdom had been allocated Le 96,586,460 (c. £29,074) by the

\footnotetext{
${ }^{7}$ See Levin (2005) for a more detailed review of these programmes.
} 
DACDF and Lower Bambara had received Le 112,363,124 (c. £33,833). As can be seen in Table 2, the annual DACDF allocation for 2005 was significantly higher, with Sandor chiefdom receiving Le 525,131,768.89 (c. £158,073), and Lower Bambara receiving Le 303,296,375.06 (c. £91,297). Chiefdom administrators in the town of Kayima (Sandor's chiefdom headquarters) report that the fund has been used effectively to finance the rehabilitation of the Native Administration (NA) police quarters and lock-up, and the community health centre. In Panguma, the chiefdom headquarters of Lower Bambara, the fund has been used for the rehabilitation and extension of the community centre.

Table 2: DACDF: Allocation of funds, 2005

\begin{tabular}{|l|l|l|c|}
\hline & $\begin{array}{l}\text { Sandor Chiefdom } \\
\text { January-June 2005 }\end{array}$ & $\begin{array}{c}\text { Sandor Chiefdom } \\
\text { July-December 2005 }\end{array}$ & $\begin{array}{c}\text { Sandor Chiefdom } \\
\text { Yearly Allocation } \\
\text { of DACDF - 2005 }\end{array}$ \\
\hline $\begin{array}{l}\text { Number of mining } \\
\text { licences issued }\end{array}$ & 455 & 451 & - \\
\hline $\begin{array}{l}\text { Total Amount Due } \\
\text { (Le) }\end{array}$ & $254,103,085.90$ & $271,028,682.99$ & - \\
\hline $\begin{array}{l}\text { Amount to District } \\
\text { Council (Le) }\end{array}$ & $50,820,617.18$ & $54,205,736.60$ & - \\
\hline $\begin{array}{l}\text { Amount to Chiefdom } \\
\text { (Le) }\end{array}$ & $203,282,468.72$ & $216,822,946.39$ & $\begin{array}{c}525,131,768.89 \\
\text { Lower Bambara } \\
\text { Chiefdom }\end{array}$ \\
\hline $\begin{array}{l}\text { Lower Bambara } \\
\text { Chiefdom }\end{array}$ & $\begin{array}{c}\text { Lower Bambara } \\
\text { Chiefdom } \\
\text { July-December 2005 }\end{array}$ & $\begin{array}{c}\text { Yearly Allocation } \\
\text { of DACDF - 2005 }\end{array}$ \\
\hline $\begin{array}{l}\text { Number of mining } \\
\text { licences issued }\end{array}$ & 218 & 211 & - \\
\hline $\begin{array}{l}\text { Total Amount Due } \\
\text { (Le) }\end{array}$ & $176,495,816.06$ & $126,800,559.00$ & - \\
\hline $\begin{array}{l}\text { Amount to District } \\
\text { Council (Le) }\end{array}$ & $35,299,163.21$ & $25,360,111.80$ & $303,296,375.06$ \\
\hline $\begin{array}{l}\text { Amount to Chiefdom } \\
\text { (Le) }\end{array}$ & $141,196,652.85$ & $101,440,447.20$ & \multicolumn{1}{|c|}{} \\
\hline
\end{tabular}

Source: Ministry of Mineral Resources (2006)

In addition to providing valuable resources for social and economic development, the fund is supposed to encourage chiefdoms to monitor mining more effectively and eradicate illegal activities, thereby enhancing the KPCS. However, the disbursement of funds and the capacity of communities to monitor development projects have provoked a considerable amount of contention among critics. For example, in 2002, a series of ad hoc reports were produced by industry observers, which revealed that a number of chiefdoms were not utilizing the fund in a competent manner. Consequently, in 2003, a DACDF Coalition was set up to ensure that the fund is used more effectively. A recent report by MSI (2004:5) reports that this Coalition - a union of representatives from the Ministry of Mineral Resources, Ministry of Local Government, national and international NGOs, the Anti-Corruption Commission and the Miners' Union - has been working 
with traditional leaders in diamondiferous chiefdoms to help chiefs improve their responsiveness to community interests and accountability for funds. The report notes:

'Constant sensitization, reporting on mis-spending, and refusal by central government to accept mismanagement of DACDF funds, has resulted in a remarkable turnaround in fiscal responsibility. Whereas fully 60 percent of the first tranche of DACDF funds disappeared, by the most recent tranche almost ninety percent of all funds were accounted for - including recovery of some of those funds missing initially'. [MSI, 2004: 4]

However, concerns over the misuse of the DACDF continued to be raised by the Government of Sierra Leone High Level Diamond Steering Committee, which eventually led to the suspension of disbursements in 2004. One of the primary issues of concern highlighted by the Committee involved an apparent lack of transparency, community awareness and local participation in decision-making processes that concerned the use of the fund. Although Chiefdom Development Committees (CDCs) have been put in place to supposedly ensure that project decision-making is carried out in an equitable and accountable manner, it is often the case that they are composed entirely of rural elites, such as section chiefs. This has reportedly stifled the concept of local ownership of the fund and alienated many stakeholders, such as women and youth (Temple, 2005). Such a situation resonates closely with the observations of other commentators who have noted that in the post-war period, the relationship between the rural elite and the 'community' at large is highly unequal, possibly fuelling a rift between youths and chiefs in the countryside. Richards (2005), for example, suggests that the war was largely a product of this division, and there continues to be considerable dissatisfaction among youths with the hierarchical political structures in rural Sierra Leone.

In short, while many chiefdoms have clearly demonstrated the capacity to utilize the DACDF effectively, it is also evident that many have not. A recent article by Jackson (2007) highlights the misuse of the fund, pointing out that, 'there is no accountability mechanism for ensuring that this cash is used for development, and it is extremely common to hear that local people complain of the chief's abuse of the system in pocketing this money' (2007:100). In comparing Sandor Chiefdom with Lower Bambara, it is evident that there is a great deal of variability in how DACDF funds have been used. According to a report published by the Integrated Diamond Management Program (IDMP) for the Government of Sierra Leone High Level Diamond Steering Committee, the accountability performance of Sandor Chiefdom was found to be very poor. According to the report, in 2004, many of the funds spent could not be accounted for by the CDC (Temple, 2005), and in 2003, a grossly disproportionate amount of the disbursement made to Sandor Chiefdom was spent on the rehabilitation of the chiefdom's native police barracks, a decision that was made solely at the discretion of the regent chief, since there was no paramount chief at the time. The report concludes that the issue of local governance in Sandor Chiefdom requires urgent attention if the DACDF is to be utilized effectively in future ${ }^{8}$.

The same report notes that although the use of DACDF funds may have been somewhat better in Lower Bambara Chiefdom, there was a slight decrease in accountability and project quality and performance between 2003 and 2004. It is suggested that this was largely because there was a desire to satisfy widespread community needs, which led to the implementation of too many

\footnotetext{
${ }^{8}$ Elsewhere, the World Bank has been highly critical of rule by the chiefs, noting that their re-instatement has been characterised by mismanagement of funds, abuse of power and an inability to deliver basic services. See World Bank (2003).
} 
projects. In 2004, nine projects (one in each section of the chiefdom) were targeted and implemented in Lower Bambara, but many of these were small and ill-funded.

In summary, although the DACDF is a well-conceived governance initiative, it has frequently been at the centre of controversy. While early disbursements from the fund were made directly to the paramount chiefs - many of whom could not account for how the funds were spent - it should, however, be noted that much has changed in Sierra Leone since the DACDF was first introduced in 2001. Most notably, the Local Government Act (2004) had not been ratified at the time the DACDF was initially proposed, and the local councils, which have now become beneficiaries, were not involved with its implementation. Although it could be argued that the decentralization process should, in theory, play an important role in improving the accountability and management of the funds, it may also be the case that the re-introduction of the local councils has caused further conflict and confusion, which could have an impact on the rational use of funds.

\section{Lessons for the Extractive Industries Transparency Initiative?}

This section of the paper considers some of the broader lessons learned from the KPCS and the DACDF, and briefly explores their implications for the implementation of the Extractive Industries Transparency Initiative (EITI) in Sierra Leone. The EITI - an extractive industries governance initiative launched by former British Prime Minister Tony Blair in September 2002 at the World Summit on Sustainable Development in Johannesburg - is a policy mechanism that has been widely celebrated by governments, Western donor agencies and international NGOs as the key to resurrecting the stagnating economies of resource-rich African countries. Based on the 'Publish What You Pay' initiative ${ }^{9}$, the EITI aims to improve the transparency of payments made by companies to governments and government-linked entities, as well as transparency of revenues received by host country governments. It is believed that a regular provision of quality information will create a system of 'checks and balances' which will assist in holding companies and governments accountable, resulting in improved economic importance, political stability and a better investment climate.

While Sierra Leone only very recently become signatory to the EITI (January 2007), there have, however, already been significant problems with its implementation. For example, unforeseen to many, the initial work plan launched by the previous government failed its EITI validation $^{10}$. The implementation work plan has since been re-submitted by the new government: Sierra Leone was recently endorsed by the international secretariat and the EITI board as a 'candidate' country. While EITI advocates have offered numerous explanations for the initial difficulties encountered in getting the initiative off the ground - many of which reflect recent changes in the political landscape following the presidential elections of August 2007 - it would appear that the challenges associated with implementing the EITI in Sierra Leone may go much deeper. Indeed, the obstacles to successful implementation are numerous, as acknowledged by the previous Minister for Presidential Affairs and current EITI Champion, Dr Shekou Sesay, in the country's EITI Keynote Address:

In pledging our commitment to the EITI, we remain conscious of the fact that its implementation comes with its own challenges - it will require consideration of some

\footnotetext{
${ }^{9}$ See http://www.publishwhatyoupay.org for further discussion of the Publish What You Pay initiative.

${ }^{10}$ Recent discussions with Allison George, World Bank consultant for EITI implementation in Sierra Leone, suggest that this failure was mainly due to a loss of focus by the EITI Steering Committee during the recent election period.
} 
complicated issues, for example, contract, confidentiality, the need for new regulation framework data, and legislation; establishment of modalities for gathering the required data; and building capacity in government and civil society to be able to competently engage in the process and use the information produced. ${ }^{11}$

One major challenge, which was also identified as a key weakness of the DACDF in the previous section, concerns the feasibility of accommodating the full participation of civil society within the EITI. Advocates maintain that the initiative is not a 'policing mechanism', but rather a tool for auditing transactions within the mining sector; the idea is that if governments and companies can be held accountable for their actions, civil society can then play a more instrumental role in ensuring that diamond revenues are spent on development priorities. The donor community has strongly encouraged the Sierra Leonean government in its implementation of the agreement by helping to facilitate a civil society coalition dedicated to promoting greater transparency in the mining sector - the National Advocacy Coalition on Extractives (NACE). However, in practice, the actual capacity of civil society to hold the government and powerful companies accountable for their actions through the use of information made available by transparent reporting remains unclear. Such a notion may be unrealistic and unachievable, especially in a fragile state such as Sierra Leone: not only is the capacity for promoting transparency and accountability low, but relatively weak civil society actors remain largely unable to monitor or challenge the power of wellestablished rent-seeking actors who are firmly established in the mining sector, in some cases since the discovery of diamonds in the 1930s. Moreover, historically there has not been a culture of transparency or accountability in the mining sector in Sierra Leone, and the concept of record keeping is still very alien. The diamond industry has been shrouded in secrecy, with multi-million dollar deals being made 'on a handshake'. As Smillie (2003: 8) notes, until 2003, tens of millions of dollars worth of diamonds were sent across borders and across continents, with little or no paper work.

In addition to issues concerning capacity, observers have also noted the importance of ensuring that civil society is accurately represented and actively engaged as a participant in the design, monitoring and evaluation of the EITI. While the previous section of the paper highlighted some of these concerns reflected within the CDCs of the DACDF, it would appear that similar issues may exist with respect to the EITI, albeit in a slightly different context. In December 2006, an EITI Steering Committee was approved by cabinet to oversee the development and implementation of the initiative. A wide range of stakeholders have been included on the committee, including representatives from the following groups: the Ministry of Presidential Affairs and Public Duty, Ministry for Mineral Resources, Ministry of Finance, Ministry of Local Government and Community Development, National Revenue Authority (NRA), National Advocacy Coalition on Extractives (NACE), the Office of National Security and the Chamber of Mines. However, resent discussions with EITI consultants in Freetown reveal that, quite surprisingly, the Council of Chiefs is absent from the committee. Although the chiefs have been roundly criticised for their abuse of power in rural areas, they are, as Jackson (2005: 55) notes, a key component of the 'basic triangle' of diamond exports, in that they retain local control over rural land. While there remains considerable debate as to how precisely the chiefs should be involved in a reformed diamond sector, they do have strong working relationships with the mining companies, and they are, in fact,

\footnotetext{
${ }^{11}$ http://www.eitransparency.org/UserFiles/File/sierraleone/sierraleone_keymoteaddress_shekou_sesay.pdf
} 
integral to the way the mining sector presently operates. The current lack of involvement by the chiefs could hinder EITI implementation, and thus the existing composition of the Steering Committee should be revised to rectify the situation.

In short, like other voluntary codes such as the KPCS, there will continue to be significant challenges associated with the implementation of the EITI in Sierra Leone. On January 2007, a provision was provided in the draft Mines and Minerals Act to support the EITI, and the Law Reform Commission (LRC) has stipulated that penalty fines are to be placed on companies, cooperatives and others making payments (e.g. exporters) for failing to comply with EITI requirements or for making false statements. But it is doubtful that this will play a meaningful role in mitigating current illegal practices. Many of the groups who are presently benefiting from illicit diamond mining and trading in Sierra Leone are firmly entrenched, and it is in their best interest to ensure that the status quo is maintained. In this respect, it is unlikely that the disclosure of payments within the diamond industry will rapidly dissolve these powerful networks. In 2006, a World Bank delegation reviewed the challenges of accomplishing this, and it was concluded that significant capacity-building is needed if the EITI is to be moved forward in Sierra Leone, the implication being that a commitment to transparency will be insufficient to break the negative linkages between natural resource wealth, poor governance, unequal development and conflict (Hilson and Maconachie, forthcoming). In the case of other weak African states with lootable resources, there is evidence to suggest that 'good governance', although often considered to be the most important criteria in the extractive industries by international donors, may not be the only consideration when trying to redress the unevenness of benefits associated with mineral wealth ${ }^{12}$.

\section{Conclusion}

In reviewing the challenges of implementing recent governance initiatives in Sierra Leone's postconflict diamond economy, it is apparent that diamonds have always been, and will likely continue to be, a 'double edged sword'. On the one hand. there have been periods in the country's recent history where diamonds have had a significant developmental impact on society and have played an important part in the national economy; but on the other hand, there have been times when they have been a destructive force, perpetuating insecurity, poverty and war. In the last decade, the international community's strong concern for 'good governance' in the management of Sierra Leone's diamond economy has undoubtedly been reinforced by wider public concern for 'blood diamonds' and their relationship to 'greed-based' insurgency. These concerns have led to a host of recently launched governance initiatives in the sector.

In considering three of these initiatives - the KPCS, DACDF and the EITI - this paper has argued that despite widespread commitment and enthusiasm, international donors, mining companies and the Sierra Leonean government will be hard pressed to address the complex issues surrounding governance in the artisanal and small-scale diamond sector on their own. In each

\footnotetext{
${ }^{12}$ Ironically, as Ferguson (2006) points out, in recent years, the African countries that have seen the biggest surge of foreign capital investment are those which might also be considered to have the worst track record in terms of governance. Putting South Africa aside, during the 1990s, it was those African countries that were plagued by corruption, human rights violations and even civil war - such as Angola, Democratic Republic of Congo, Equatorial Guinea and Sudan - that attracted the most capital investment and performed the best in terms of economic growth (Reno, 2001, cited in Ferguson, 2006). In contrast, those African countries that appeared to be more stable and demonstrated better records of democracy, privatization and 'good governance' did not perform as well.
} 
case, it has been demonstrated that the introduction of complex monitoring processes has provided significant challenges for a country which is emerging from a long period of conflict and isolation, suffering from serious shortages in human capacity, and where good governance and accountability will undoubtedly take considerable time to develop.

While power structures within Sierra Leonean society remain hierarchical and highly uneven, making the equitable participation of civil society a great challenge, it will also prove difficult to eliminate the complex network of actors that have long sustained the corruption and lack of transparency that characterize local diamond extraction. In short, these aspects of Sierra Leone's mining sector present very real challenges for full EITI implementation. The fact that the country has now achieved candidacy status and has developed a publicised EITI work plan is a positive first step. However, the challenges ahead will be difficult to meet, not least because smallscale mining is chaotic, unregulated and virtually impossible to control, but also because so many powerful groups have a vested interest in continuing to exploit diamond reserves illegally and ensuring that the status quo is maintained. 


\section{References}

Adebajo, A. (2002) Sierra Leone: a feast for the Sobels. In: Adebajo, A. (ed.) Building Peace in West Africa: Liberia, Sierra Leone and Guinnea-Bissau. International Peace Academy Occasional Paper Series. London: Lynne Rienner, pp. 79-109.

Bryceson, D.F. and V. Jamal (1997) (eds.) Farewell to Farms: De-agrarianisation and Employment in Africa. Aldershot: Ashgate.

Campbell, B. (2003) Factoring in governance is not enough: mining codes in Africa, policy reform and corporate responsibility. Minerals Energy - Raw Materials Report, 18 (3), pp. 2-13.

Collier, P. and A. Hoeffler (2005) Resource rents, governance and conflict. Journal of Conflict Resolution, 49, 4, pp. 625-633.

Collier, P. and A. Hoeffler (2001) Greed and Grievance in Civil War. Policy Research Working Paper no. 2355. World Bank, Washington, D.C.

Davies, V. (2006) 'Diamonds, poverty and war in Sierra Leone'. In: Hilson, G. (ed.) (2006) SmallScale Mining, Rural Subsistence and Poverty in West Africa. Intermediate Technology Publications, Rugby, pp. 165-180.

Diamond Development Initiative (DDI) (2005) Diamond Development Initiative: Background Note. Accra Conference, October 27-30, 2005. Accessed at http://casmsite.org/Documents/DDI Accra Oct05.pdf

Elbadawi, I. and N. Sambanis (2002) How much war will we see? Estimating the prevalence of civil war in 161 countries, 1960-1999. Journal of Conflict Resolution, 46 (2), June 2002, pp. 307-334.

Ellis, F. (1998) Household Strategies and Rural Livelihood diversification. The Journal of Development Studies, Vol. 35, No. 1 October 1998, pp. 1-38.

Even-Zohar, C. (2003) Financial Constraints Study, June 2003. Accessed at www.peacediamonds.org

Fearon, J. (2004) 'Primary commodity exports and civil war.' Journal of Conflict Resolution, 49, 4, pp. 483-507.

Ferguson, J. (2006) Global Shadows: Africa in the Neoliberal World Order. Durham: Duke University Press.

GAO (2006) United States Government Accountability Office. Report to Congressional Committees. 'Conflict diamonds: agency actions needed to enhance implementation of the Clean Diamond Trade Act'. Accessed at: http://www.gao.gov/new.items/d06978.pdf.

Gberie, L. (2002) War and Peace in Sierra Leone: Diamonds, Corruption and the Lebanese Connection. Ottawa: Partnership Africa Canada.

Global Witness/ Partnership Africa Canada (2004) Rich Man Poor Man: Development diamonds and poverty diamonds. Ottawa: Global Witness/PAC.

Hilson, G. (2008) 'Fair trade gold': Antecedents, prospects and challenges. Geoforum, 39, pp. 386400. 
Hilson, G. and R. Maconachie (forthcoming) 'Good governance' and the extractive industries in sub-Saharan Africa. Mineral Processing and Extractive Metallurgy Review.

Jackson, P (2007) Reshuffling an old deck of cards? The politics of local government reform in Sierra Leone. African Affairs, 106/422, pp. 95-111.

Jackson, P. (2005) Chiefs, money and politicians: re-building local government in post-war Sierra Leone. Public Administration and Development, 25, pp. 49-58.

Keen, D. (2005) Conflict and Collusion in Sierra Leone. James Currey, Oxford.

Labonne, B. (1999) The mining industry and the community: joining forces for sustainable social development. Natural Resources Forum, 23, 4, pp. 315-322.

Le Billon, P. (2006) Fatal Transactions: conflict Diamonds and the (Anti) Terrorist consumer. Antipode, September 2006. Vol. 38, Issue 4, pp. 778-801.

Levin, E. (2005) 'From Poverty and War to Prosperity and Peace? Sustainable Livelihoods and Innovation in Governance of Artisanal Diamond Mining in Kono District, Sierra Leone'. Unpublished Masters Dissertation, Department of Geography, The University of British Columbia.

Maconachie, R and T. Binns (2007) 'Farming miners' or 'mining farmers'?: Diamond mining and rural development in post-conflict Sierra Leone.' Journal of Rural Studies, 23, pp. 367-380.

Management Systems International (MSI) (2004) Integrated Diamond Management in Sierra Leone: a Two-year Pilot Project. Report prepared for assistance of the United States Agency for International Development, April 2004, Washington D.C.

Mbabazi, P., S. Maclean and T. Shaw (2002) Governance for reconstruction in Africa: challenges for policy communities and coalitions. Global Networks, 2, pp. 31-47.

Ministry of Mineral Resources (2004) Summary of Allocation of Diamond Area Community Development Fund. Mines Division, Kono.

Network Movement for Justice and Development (NMJD) (2007) Paradise Lost?: Profiles of Small to Large Scale Mining Companies Operating inn Kono District. Freetown: NMJD, June 2007.

Noyes, F. (2003) Preventive diplomacy in Sierra Leone. In: Solomon, H. (ed.) Towards Sustainable Peace: The Theory and Practice of Preventive Diplomacy in Africa. The Africa Institute of South Africa, Pretoria, pp. 44-99.

Ocheje, P. (2006) The Extractive Industries Transparency Initiative (EITI): Voluntary codes of conduct, poverty and accountability in Africa. Journal of Sustainable Development in Africa, 8, 3, pp. 222-239.

Olsson, O. (2006) Diamonds are a Rebel's best friend. The World Economy 29 (8), pp. 1133-1150.

Overseas Development Institute (ODI) (2006) Governance, development and aid effectiveness: a quick guide to complex relationships. Briefing Paper March 2006. London: ODI.

Partnership Africa Canada (2006) Killing Kimberley? Conflict Diamonds and Paper Tigers. Occasional Paper 15. Ottawa: Partnership Africa Canada, November 2006. 
Partnership Africa Canada/Network Movement for Justice and Development (2006) Diamond Industry Annual Review: Sierra Leone 2006. Ottawa: Partnership Africa Canada/Network Movement for Justice and Development.

Reno, W. (2001) How sovereignty matters: international markets and the political economy of local politics in weak states. In: Callaghy, T.M., R. Kassimir and R. Latham (eds.) Intervention and Transnationalism in Africa: Global-Local Networks of Power. New York: Cambridge University Press.

Richards, P. (2005) To fight or to farm? Agrarian dimensions of the Mano River conflicts (Liberia and Sierra Leone). African Affairs, Vol. 104, Number 417, October 2005, pp. 571-590.

Richards, P. (2003) The political economy of internal conflict in Sierra Leone. Working Paper 21. Netherlands Institute of International Relations 'Clingendael', Conflict Research Unit, August 2003.

Richards, P. (1996) Fighting for the Rainforest: War, Youth and Resources in Sierra Leone. Oxford: James Currey.

Ross, M.L. (2003) Oil, drugs and diamonds: The varying roles of natural resources in civil war. In: Ballentine, K. and J. Sherman (eds.) The Political Economy of Armed Conflict: Beyond Greed and Grievance. Lynne Rienner Publishers, Boulder and London, pp. 47-70.

Silberfein, M. (2004) The geopolitics of conflict and diamonds in Sierra Leone. Geopolitics, 9 (1), pp. 213-241.

Smillie (2006) Forward. In: Hilson, G. (ed.) (2006) Small-Scale Mining, Rural subsistence and Poverty in West Africa. Intermediate Technology Publications, Rugby, pp. xi-xii.

Smillie, I. (2003) Motherhood, Apple Pie and False Teeth: Corporate Social Responsibility in the Diamond Industry. Occasional Paper 10. Ottawa: Partnership Africa Canada, June 2003.

Smillie, I., L. Gberie and R. Hazleton (2000) The Heart of the Matter. Sierra Leone, Diamonds and Human Security. Partnership Africa Canada, Ottawa.

Strasser-King, V.E.H. (2004) The Kimberley process in Sierra Leone and the need for legislation. Paper presented at the Law Reform Commission, Mines and Minerals Seminar on the Development of a Consolidated Mines and Minerals Act for Sierra Leone. November 18-19, 2004, Freetown.

Temple, H. (2006) Livelihoods Report. Report prepared for DfID, 2006, Freetown.

Temple, P. (2005) 'Improving the effective use of the Diamond Area Community Development Fund (DACDF).' Report by the Integrated Diamond Management Program (IDMP) for submission to the Government of Sierra Leone High Level Diamond Steering Committee (HLDSC). Management Systems International, Washington, DC.

UNDP (2007a) Sierra Leone Human Development Report 2007. Freetown: UNDP.

UNDP (2007b) Human Development Report 2007/2008. UNDP. Accessed at http://hdr.undp.org/en/reports/global/hdr2007-2008/

Van der Laan, H.L. (1965) The Sierra Leone Diamonds. Oxford: Oxford University Press.

World Bank (2003) Sierra Leone: Strategic options for public sector reform. Report no. 25110. Washington DC, 2003. 
The Brooks World Poverty Institute (BWPI) creates

Executive Director

Professor Tony Addison

Research Director

Professor Michael Woolcock

\section{Associate Director}

Professor David Hulme

\section{Contact:}

Brooks World Poverty Institute

The University of Manchester

Humanities Bridgeford Street

Building

Oxford Road

Manchester

M13 9PL

United Kingdom

Email: bwpi@manchester.ac.uk and shares knowledge to help end global poverty.

BWPI is multidisciplinary, researching poverty in both the rich and poor worlds.

Our aim is to better understand why people are poor, what keeps them trapped in poverty and how they can be helped - drawing upon the very best international practice in research and policy making.

The Brooks World Poverty Institute is chaired by Nobel Laureate, Professor Joseph E. Stiglitz. 